\title{
A Comparative Analysis of Temporal Structure of English Poetic Texts for Adults and Children
}

\author{
Nataliya Denisova \\ National Research University Higher School of Economics \\ Correspondence concerning this article should be addressed to Nataliya Denisova, Department of English \\ Language for Social Sciences, National Research University Higher School of Economics., 33 Kirpichnaya \\ st., Moscow, Russian Federation, 105187. E-mail: denisova-nt@mail.ru \\ Dinara Yusipova \\ National Research University Higher School of Economics

\begin{abstract}
Correspondence concerning this article should be addressed to Nataliya Denisova, Department of English Language for Social Sciences, National Research University Higher School of Economics., 24 Staraya Basmannaya st., Moscow, Russian Federation, 105066. E-mail: dyusipova@hse.ru
\end{abstract}

\begin{abstract}
Poetry has always been under the focus of scholars' attention, though the problem of performing a comparative analysis of children's and adults' poetry has not received enough attention yet. The study undertaken is aimed to fill in this gap and provide the analysis of English poetry for adults and children with the attempt to identify some grammatical peculiarities of the corresponding poetic texts. The scope of the texts for examination is limited to English poetry of the nineteenth - twentieth centuries focused on the animal theme. The analysis of the temporal structure of the texts selected was based on the method elaborated by Ludmila Nozdrina in her work "Poetics of grammar categories" (2004). The results of the study have proved the hypothesis stated: there are some differences in temporal structuring of the nineteenth-twentieth century poetic English texts focused on the animal theme. The main difference lies in targeting the poem: whether it appeals to adults or children. The current study contains quantitative information on the usage of certain grammatical phenomena within the texts analyzed, and the attempts of their interpretations. Consequently, the study might be of particular interest for those scholars who do research on differentiating grammatical peculiarities of poetry in general and drawing differences between children's and adults' poetry, in particular.
\end{abstract}

Keywords: poetry, English poetry, literature for adults and children, text analysis, grammar, animals

Poetry in general and English poetry in particular has always attracted the attention of scholars: take for instance, the works of Harriet Beecher Stowe (1870) or Aleksey Bartoshevich (2014). Nevertheless, as the study has revealed, the number of works dealing with the comparative analysis between children's and adults' poetry is relatively small (Anderson, 1984; Churchill, 1999). This article aims to fill in this gap and provide the analysis of English poetry for children and adults with the attempt to identify some grammatical peculiarities of the corresponding poetic texts. Limiting the scope of the texts for examination there has been selected
English poetry of the nineteenth - twentieth centuries with a special focus on the animal theme. By poems focused on the animal theme we understand the poems where animals stay as subjects or objects of narration.

The grammatical aspects of poetic texts have been scrutinized by many outstanding linguists, such as Roman Jakobson (Jakobson, 1960), Noam Chomsky (Chomsky, 1957), Samuel Levin (1965), Michael Halliday (1961), and contemporary less famous scholars, for example, Antonina Harbus (2012). The study that has served the base in choosing the method for analyzing grammatical peculiarities of the poetic 
texts for children and adults is "Poetics of grammar categories" by Ludmila Nozdrina (2004). The researcher examines the role the grammar categories play in the text structure while the text is performing its main artistic-aesthetic function (Nozdrina, 2004). Having distinguished several "networks" within the structure of the text, Nozdrina explores each of them according to some parameters specially created (Nozdrina, 2004). The method Nozdrina offers for the analysis of the temporal structure of literary texts has been chosen for accomplishing the purposes of the study.

For the purpose of this study, a hypothesis was formulated. It is: there exist some differences in temporal structuring of the nineteenth-twentieth century English poetic texts with the animal theme as the focus. What underlies the differences is targeting the poems: whether they appeal to children or adults.

\section{Materials and Methods}

\section{Literature Review}

The number of scientific studies dealing with different approaches to examining poetry, including English poetry, is relatively big. Poetic texts are being scrutinized within different sciences: cognitive linguistics (Borkent, 2010; Harbus, 2012; Stockwell, 2002), stylistics (Thorne, 1969; Goncharenko, 1988), sociolinguistics (Fowler, 1981; Samson, A. (2005), pedagogy (Koch, 1971; Sloan, 2001) cultural studies (Damon, Livingston, 2009; DuPlessis, 2012), and so on.

It is important to note that while adult poetry has always been under the focus of scholars' attention, the interest for analyzing children's poetry has appeared only recently (Churchill, 1999, p.1). The last decades have been marked by the appearance of a number of works on literature for children, including children's poetry, for instance, a profound study made by Pavlova (2011), which is connected with the examination of socio-linguistic characteristics of communicative space in English and Russian verses for children. Another scholar, Kilcup (2008), has divided the American children's poetry of the nineteenth century thematically, thus, creating an anthology of such poems. One more example worth mentioning is the work by Sokolova (2013) where communicative strategies in PR, agitation, and avant-garde poetic texts aimed at children are studied.

There exists a variety of textual texts referring to children's poetry. According to Schellenberg, “Children's poetry seems to incorporate not only verses written for children, but also poetry written about children, poetry written by children, and (a troublingly indeterminate category) poetry that children enjoy" (Schellenberg,
1996, pp. 7-8). For the purposes of the study the scope of poems under consideration has been limited to the only text type - poetic texts written for children.

A number of studies have appeared recently where the authors have made attempts to examine some differences between poetry for adults and children (Pavlova, 2011; Churchill, 1999). One of the works that deserves attention is the study by Pavlova (2011), who has managed to provide some peculiarities of children's poetry on different language levels of poetry texts (lexico-morphological, syntactic, and phonetic) in comparison with the corresponding texts written for adults (Pavlova, 2011). The author declares against the consideration of children's poetry as simple or primitive in comparison with the one for adults. She accentuates that "Apparent simplicity is just not very high lexical and grammar saturation of the text, the lack of complex syntactical structures and abstract notions" (Pavlova, 2011, p. 16), making an emphasis here on the importance of plot and composition (Pavlova, 2011, p. 16). Pavlova argues that at the lexical level, the peculiarities of poetic texts for children in comparison with those for adults become apparent through "maximization of lexical units, that correlates with visual-image type of thinking" (Pavlova, 2011, p. 52). At the syntactical level, the scholar lays an emphasis on a higher explicit expressiveness of the texts written for children in comparison with poetic texts for adults (Pavlova, 2011, p.51). As for morphological level, Pavlova stresses "the predominance of nouns, verbs over a small number of adjectives in poetic texts for children which reflects a step-by-step succession of familiarization with these parts of speech in the ontology of speech development" (Pavlova, 2011, p. 174).

There exist some studies where the researchers, while analyzing the poetry of one particular poet, draw the differences between his approaches to creating verses for adults and children (Churchill, 1999; Ritvo, 1985; Tricker, 2001). For example, Churchill (1999), providing the analysis of children's poetry of such American Modernist writers as Lindsay, Benet and Sandburg, accentuates that their children's poetry "is of a piece with their writing for adults" in contrast to Eliot's Practical Cats (the poem given as the example of Eliot's poetry for children), which "stands in complete opposition to Eliot's major poetic works" (Churchill, 1999; Ritvo, 1985; Tricker, 2001, p. 171).

While differentiating the most popular poetic themes, many scholars distinguish an animal topic as one of the most frequently used in creating verses for both: children and adults (Stepanova, 2003; Pavlova, 2011). This fact has determined choosing the themes for selecting the poems for further detailed examination.

The study undertaken is aimed at revealing some peculiarities of poetic texts on the temporal level. 
That is why it has required the study of corresponding scientific literature dealing with examination of grammar aspects of poetry. One of the most prominent linguists, Jakobson, (1960) suggested a functional definition of poetic language having defined the main constitutive factors any kind of communication is based on (Jakobson, 1960). Chomsky (1957) has introduced the theory of transformational-generative grammar, which was further used by many scientists in their analysis of poetic texts. (See, for example, the study by Levin (1965). The approach within categoryscale grammar developed by Halliday (1961) supposes to examine English syntax on the basis of "rank-scale" of units: sentence, clause, group, word, morpheme (Halliday, 1961).

A significant number of modern scientific works on literary texts, poetic texts as well, deals with a cognitive approach, which implies an approach from the view of man's perception of the surrounding world. The work "Poetics of grammar categories" by Nozdrina (2004) is one of the studies within such an approach, which is aimed at showing the role grammar categories play in the text structure while the text is fulfilling its main, artistic-aesthetic function. The interaction between grammar aspect and other aspects, such as lexical, word formation and phonetic ones is taken into account (Nozdrina, 2004, p. 6). Four grammar categories are considered: the category of time, person, mood and definiteness/indefiniteness. Each grammar category is considered as the main means for creating the corresponding text structure: time category - as the means for creating temporal structure, mood modal, person - personal, definiteness/indefiniteness - referential structure of the text. The researcher adds one more structure - the local text structure (Nozdrina, 2004).

The approach presented by Nozdrina in the part concerning the analysis of the temporal network of literary texts has served as an instrument for the examination of poetic texts in the research conducted. The next part of the article will present more detailed explanation of this method, which underlies the analysis of English poetry for adults and children.

\section{Methodology}

The main aim of the study performed is to draw the differences in the temporal structuring of the nineteenth-twentieth century poetic English texts taking into account the target audience of the poems: adults or children. To achieve the aim of the study the approach to the analysis of temporal structure developed by Nozdrina (2004) has been chosen. It is important to note that the temporal structure constitutes only one element of the whole system of examining the text based on the network text analysis together with local, modal, personal as well as the referential structures. The size of the article does not give an opportunity to provide the whole network analysis of the poetic texts, thus it has been decided to focus only on one aspect of such analysis, connected with the temporal structure.

To describe contextual text structures, the researcher introduces the notion a "textual network" which is represented by a set of language means (morphological, syntactic, lexical, word-formation) expressing precise semantic context (temporality, modality and so on) (Nozdrina, 2004, p. 52). A textual network is a syntagmatic category peculiar to speech. The network is very important in poems as it helps understand the poet's technique and interpret the plot and the message of the poem as a whole. To draw differences between various texts within a certain textual network (for example, temporal network), Nozdrina has introduced such parameters as net composition, net picture, rhythm of transition, and net conditionality. To distinguish between the components within these parameters, the method of opposition is used (Nozdrina, 2004, p. 53).

According to Nozdrina, the pattern of temporal network is a graphically depicted transition from one tense form to another to involve the reader into the action, to compare and contrast between the present and the past (Nozdrina, 2004, p. 79). The temporal network expresses movements in time of the author and other participants. In order to express time in general and the exact time of the action in particular, writers resort to the usage of the variety of tenses, nouns, adverbs and numerals.

In this study it will be examined the use of tenses in poetic texts written for adults and children to state some differences in their structuring. The composition of the temporal network will be analyzed on the basis of the criteria proposed by Nozdrina (Nozdrina, 2004, p. 78).

The temporal network, as Nozdrina suggests, can be monotemporal (only one tense is used) and polytemporal (two or more tenses are used). The scholar accentuates the main tasks grammatical time plays in a monotemporal text for artistic purposes of the texts. The single tense which is used throughout the poem makes it cohesive. It creates the "barrier effect" between the real world and the world of the characters of the poem; between the real time and artistic time. It also makes an attempt to plunge the reader into the present situation and involve him into the action (Nozdrina, 2004, p. 69). As far as polytemporal network is concerned, the tasks the grammatical tense plays in this kind of texts, are different to some extent. The use of various tenses in the text contributes to the creation of temporal discontinuum, lyrical mood of the whole artistic text with the often change of lyrical characters' 
feelings, artistic rhythm and the time of the plot of the narration. It also focuses the reader on the main action by switching to another grammatical time structure and draws difference between compositional parts of the text (Nozdrina, 2004, p. 75).

Defining other parameters for comparison within the temporal network Nozdrina differentiates between a single-layered temporal network (there is only one plan of narration - the author's one) and a multilayered network (the direct speech of characters is present as well) (Nozdrina, 2004, p. 75). The researcher distinguishes a definite network (the exact time of the action is present) and indefinite (the exact time of the action is absent) (Nozdrina, 2004, p. 75). These particular parameters have been applied further in the analysis of poetic texts for children and adults.

\section{Results and Discussion}

In this research 50 poems by British and American writers have been analyzed: 25 - for children and the other 25 - for adults (see Appendix 1). The limitation refers to the topic of the poems. The animal theme has been chosen being one of the most popular one. The analysis of the temporal networks of the texts was based on the approach elaborated by Nozdrina (2004).

The quantitative analysis was employed to define percentagewise the number of poetic texts (written for children or adults) sharing certain characteristics to the overall number of poetic texts (25 in each category). The goal of the study has been to examine the temporal structures of the texts chosen so that to prove that they have some differences depending on the audience to appeal. The results obtained during the analysis of the nineteenth-twentieth century poetic English texts written for children and adults (focused on the animal theme) are presented in the table and the bar chart. The table contains the information on the usage of grammar times in corresponding poetic texts given in percentage terms. The bar chart reflects the peculiarities of the compositional network of the same texts. The table and the bar chart are supplied by comments describing the results obtained and giving possible explanations and the author's interpretations of the data provided.

The first aspect to analyze is the usage of grammar tenses within two types of texts: for children and for adults (see Table 1). The most noticeable difference appears in the use of the Past Simple tense. In poetry for adults the percentage of this tense use is $80 \%$ while in poetry for children it is approximately two times less (48\%). This evident contrast may be traced to the reader's age gap. Adults, in contrast to children, have got more comprehensive experience and the ability to compare and assess their actions in the past. The Past Perfect tense in adults' poetry is used in $12 \%$ of such poems (that is the lowest indicator in the use of grammar tenses in the selected poetic texts for adults) while in children's poetry there was no manifestation of this tense. It might be suggested that it is the complex structure of the Past Perfect tense that has determined its poor representation in poetic texts in general: "For She who planned the mossy lodge, Mistrusting her evasive skill, Had to a Primrose looked for aid Her wishes to fulfill" (A Wren's Nest by William Wordsworth); "Eagerly I wished the morrow; - vainly I had sought to borrow From my books surcease of sorrow- sorrow for the lost Lenore - For the rare and radiant maiden whom the angels name Lenore - Nameless here for evermore" (The Raven by Poe Edgar Allan) To add to this, that complex grammatical structure could create apparent difficulties for understanding by children. Another vivid fact is the absence the Past Continuous Tense in the poetic texts for children; it is still presented in $16 \%$ of adult poetic texts. It is possible to suppose that the older audience could pay much more attention to details trying to focus on the development of some processes and states. As for the Present Continuous tense, it is used twice more often in poetry for adults (16\% vs $8 \%$ ). This fact is also connected with the world perception by these two audiences: for children might be more important to see the routine, for example, of some animals), while adults seem to be more interested in the process, in a way something happens. It might, as well, explain a slight difference in the use of the Present Simple tense. It is essential to emphasize that in poetry for children, with an animal being the main character, this tense, as a rule, is used to describe the animal's appearance and the routine of its life; in adult poetry the Present Simple tense, as it was discovered, helps to describe a person's character through the description of animals' habits.

The percentage of the Future Simple tense is more than twice higher in poems for adults ( $32 \%$ vs $12 \%)$. It could be explained by the fact that older people, as a rule, make plans and speculate about the future. The usage of the Future in the Past Tense in both types of poetry is relatively equal (16\% in poems for children and $20 \%$ in poems for adults). As the study revealed, in both types of texts the Future in the Past Tense is used, mostly, to impart modality to the narration.

The Present Perfect tense is also more often used in adults' poems: the usage of this tense is a third more in such poems in comparison with the poems for children. It may be referred to the complex and, consequently, more difficult for perceiving structure of the Present Perfect tense: "Minnaloushe creeps through the grass From moonlit place to place, The sacred moon overhead Has taken a new phase" (The Cat And The Moon by William Butler Yeats). 
Table 1

Temporal network (1)

\begin{tabular}{|c|c|}
\hline \multicolumn{2}{|c|}{ Temporal network } \\
\hline Poems for adults & Poems for children \\
\hline \multicolumn{2}{|c|}{ Past Simple } \\
\hline $80 \%$ & $48 \%$ \\
\hline \multicolumn{2}{|c|}{ Past Perfect } \\
\hline $12 \%$ & $0 \%$ \\
\hline \multicolumn{2}{|c|}{ Past Continuous } \\
\hline $16 \%$ & $0 \%$ \\
\hline \multicolumn{2}{|c|}{ Present Continuous } \\
\hline $16 \%$ & $8 \%$ \\
\hline \multicolumn{2}{|c|}{ Present Simple } \\
\hline $68 \%$ & $76 \%$ \\
\hline \multicolumn{2}{|c|}{ Future Simple } \\
\hline $32 \%$ & $12 \%$ \\
\hline \multicolumn{2}{|c|}{ Future in the past } \\
\hline $20 \%$ & $16 \%$ \\
\hline \multicolumn{2}{|c|}{ Present Perfect } \\
\hline $36 \%$ & $24 \%$ \\
\hline
\end{tabular}

Figure 1. Temporal network (2).

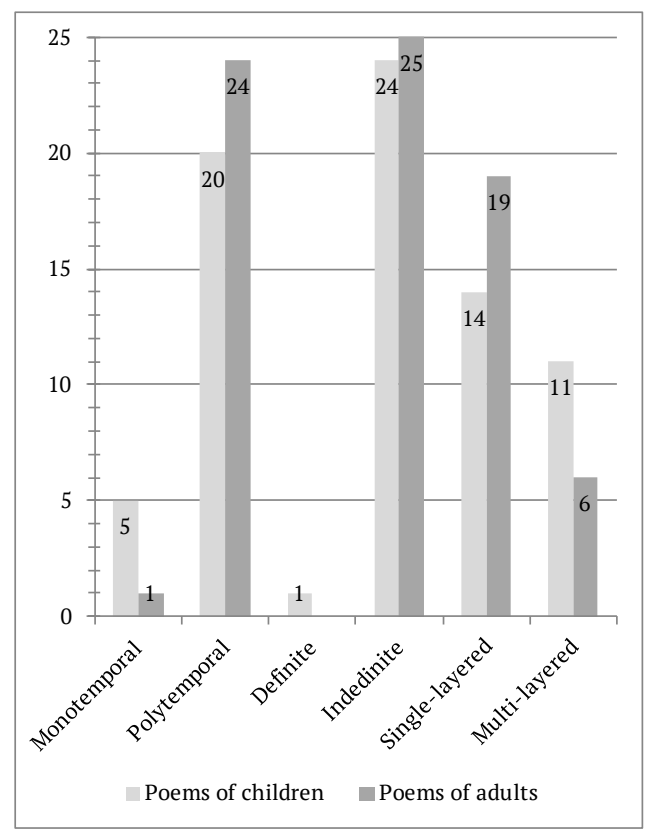

Figure 1. Temporal network (2).

The most striking feature which is peculiar to the compositional structuring of the analyzed texts concerns the opposition definiteness/indefiniteness in determining the time of action (see Figure 1). In fact, only one poem written for children (though it might be referred to both: children and adults' poetry as well) contains a definite indication of time: "And as long after what happened here On the twenty-second of July, Thirteen hundred and seventy-six" (The Pied Piper of
Hamelin by Robert Browning). It could be explained by the specific genre of literature the poetic texts refer to. Poetry is known to reflect a lyrical mood, mostly dealing with feelings and lyrical speculations, the exact time is the last thing to be mentioned here, which is proved by the study conducted. Another peculiarity concerns the number of grammar times used in the texts under analysis: the general tendency in both types of texts is in more complex structuring based on the use of different tenses showing the change in the plot of narration as well as the characters' mood and thoughts. The majority of poetic texts for adults have got polytemporal structure while the fifth part of the children's texts is characterized by monotemporal structure. The choice for one tense to use may be explained by the desire of the authors to make the plot of narration and the way of familiarizing children with animals easier. Speaking about the plan of narration it is possible to see that the common tendency peculiar for the texts in general is the prevailing single-layered network, though there is no significant difference in the use of one particular network in poetry for children with a slight priority for single-layered structure (14\% vs $11 \%)$. Including dialogues in the text of narration makes it more vivid and emotionally saturated. In animal poetry, attaching human characteristics to the animal characters and involving them in dialogues gives opportunities to speak allegorically and deliver some hidden messages about political, economic, social and other spheres of social life as it is done, for instance, in the poem The Pied Piper of Hamelin by Robert Browning. This method is often used in poetry for adults (for example, satire). The presence of dialogues in children's poetry makes the narration more fascinating and often fulfills an educational role, familiarizing children with the main customs and traditions of the society (in this case, British and American), and teaching children the established ways of behavior, for example, in Three Little Kittens by Eliza Follen. Presenting information in the form of a dialogue amuses children, makes them be more involved in the narration and simplifies the way of perceiving and assimilation of information. Adults, as it is known, have better abilities in understanding and interpreting information. These facts could explain the predominance (though a slight one) in existence of the single-layered network in adults' poetry in comparison with the children's one (19\% vs 14\%).

To illustrate the differences revealed in the temporal structure of the poems focused on the animal theme written for children and adults, it seems reasonable to give examples of two poems: The Cow by Robert Louis Stevenson (written for children) and To the Snake by Denise Levertov (written for adults).

The temporal network of the poem for children (The Cow) could be characterized as monotemporal (with The Present Simple being the only tense in the poem), indefinite (no definite time of action being indicated), 
Table 2

Two poems compared

\begin{tabular}{|c|c|}
\hline Poetry for children & Poetry for adults \\
\hline The cow by Robert Louis Stevenson & To the Snake by Denise Levertov \\
\hline $\begin{array}{l}\text { The friendly cow all red and white, } \\
\text { I love with all my heart: } \\
\text { She gives me cream with all her might, } \\
\text { To eat with apple-tart. } \\
\text { She wanders lowing here and there, } \\
\text { And yet she cannot stray, } \\
\text { All in the pleasant open air, } \\
\text { The pleasant light of day; } \\
\text { And blown by all the winds that pass } \\
\text { And wet with all the showers, } \\
\text { She walks among the meadow grass } \\
\text { And eats the meadow flowers. }\end{array}$ & $\begin{array}{l}\text { Green Snake--I swore to my companions that } \\
\text { certainly } \\
\text { you were harmless! But truly } \\
\text { I had no certainty, and no hope, only desiring } \\
\text { to hold you, for that joy, } \\
\text { which left } \\
\text { a long wake of pleasure, as the leaves moved } \\
\text { and you faded into the pattern } \\
\text { of grass and shadows, and I returned } \\
\text { smiling and haunted, to a dark morning. }\end{array}$ \\
\hline
\end{tabular}

single-layered (with only one plan of narration). The temporal network of the poem for adults (To the Snake) has got the same characteristics concerning the plan of narration (being single-layered), definiteness of the time of action (being indefinite) but differs in the usage of tenses in the poem: in contrast to the previous poem, the only tense used in the poem To the Snake is The Past Simple Tense. As it was revealed earlier in this study, it was The Present Simple tense that was the most often used tense for describing actions and states in the poetic texts for children, while The Past Simple tense was the most frequently used one for the same purposes in the corresponding texts for adults. In this respect, The Cow by Robert Louis Stevenson and To the Snake by Denise Levertov serve good illustration for this phenomenon.

To sum up, it should be stated that the analysis of English poems for children and adults( limited by the animal theme) with the help of textual network analysis has revealed some common features and differences in grammatical structuring of the poetic texts considered. The characteristics that both two types of texts have in common within their temporal network concern the lack of definiteness in indicating certain time of the actions in poems. Both types of texts have predominance in the use of various tenses (not the single one) within their structures. The Present Continuous and Present Perfect have been used approximately two times more in adults' poetry in comparison with the children's poetry. The Past Simple tense has been discovered as the most frequently used in the texts for adults, while the Present Simple tense is more common in the texts for children. The texts with direct speech of the characters are more spread within poetic texts for children. The main difference in the temporal network of two types of the texts lies in the usage of the Past Perfect and Past
Continuous tenses, manifestation of which has not been found at all in the children's poetic texts under analysis. The common features mentioned above could be referred to the fact that the texts studied belong to the single genre - poetry - thus, common characteristics might be general to all poetic texts. The differences could be explained by various approaches to perceiving the world, and poetry, in particular, by children and adults, and the aspiration of the authors writing for them to meet the expectations of these two audiences.

\section{Conclusion}

This article focused on examination of English poetry (British and American) for adults and children. The study of English poetic texts of the nineteenth twentieth centuries focused on the animal theme has proved the hypothesis provided at the beginning of the article, that there exist some differences in temporal structuring of such texts depending on whom these texts are intended: adults or children. The compositional temporal structures of these two types of texts vary in the way the grammar tenses are used as well as the preferences for a certain type of narration. It is possible to suggest, the main discrepancies may be explained by the authors' aspiration to comply with the various perception of reality, including a poetic world, by adults and younger readers.

It is possible to suggest that quantitative indicators that have been revealed within the temporal network of the texts may vary depending on specific children's or adults' poems chosen for consideration. This study examined poems related to the animal topic, though 
other themes may also be taken for the similar texts examination. Moreover, it could be challenging in further research to expand the possibilities of using the methodology elaborated by Nozdrina (2004) and apply network text analysis to the consideration of poetic texts differentiating within the whole range of networks distinguished by the author: temporal, local, personal, referential, and modal. In general, the data, including qualitative ones, presented in the current study might be of practical use for those scholars who aim at revealing grammatical peculiarities of poetic texts as a whole, and the researchers who investigate the possibilities to differentiate between children' and adults' poetry.

\section{References}

Anderson, C. C. (1984). Style in children's literature: A comparison of passages from books for adults and for children (Unpublished doctoral dissertation). University of Rhode Island, Kingston, RI. Retrieved from http://digitalcommons.uri.edu/dissertations/ AAI8501269

Bartoshevich, A. (2014). Hronika Shekspirovskogo goda [The chronicle of Shakespearian year]. Znanie. Ponimanie. Umenie, 2, 224-235.

Beecher Stowe, H. (1870). A history of the Byron controversy: From its beginning in 1816 to the present time. Boston, MA: Fields, Osgood, \& Co.

Blau DuPlessis, R. (2012). Social texts and poetic texts: Poetry and cultural studies. Oxford, UK: Oxford University Press.

Borkent, M. (2010). Illusions of simplicity: A cognitive approach to visual poetry. English Text Construction Journal, 3(2), 145-64.

Chomsky, N. (1957). Syntactic structures. The Hague, Netherlands: Mouton.

Churchill, S. (1999). Taken seriously: American modernist children's poetry (Unpublished doctoral dissertation). Auburn University, Auburn, AL. Available from UMI Company database. (UMI № 9939612).

Damon, M., Livingston, I. (2009). Poetry and cultural studies. Champaign, IL: University of Illinois Press.

Fowler, R. (1981). Literature as social discourse: The practice of linguistic criticism. Bloomington, IN: Indiana University Press.

Goncharenko, S. (1988). Stilisticheskij analiz ispanskogo stihotvornogo teksta (osnovy teorii ispanskoj pojeticheskoj rechi) [Stylistic analysis of the Spanish text (the basis of the theory of Spanish poetic speech)]. Moscow, USSR: Vysshaja shkola.

Halliday, M. (1961). Categories of the theory of grammar. Word, 17, 241-292.

Harbus, A. (2012). Cognitive approach to old English poetry. Cambridge, UK: D. S. Brewer.

Jakobson, R. (1960). Closing statements: Linguistics and poetics. In Th. A. Sebeok (Ed.), Style in language (pp. 350-377). Cambridge, MA: MIT Press.

Kilcup, K. L., Sorby, A. (2014). Over the river and through the wood: An anthology of nineteenth-century American children's poetry. Baltimore, MD: Johns Hopkins UP.

Koch, K. (1971). Wishes, lies, and dreams: Teaching children to write poetry. New York, NY: Vintage.

Kutiper, K., Wilson, P. (1993). Updating poetry preferences: A look at the poetry children really like. The Reading Teacher Journal, 47, 28-35.

Levin, S. (1965). Internal and external deviation in poetry. Word, 21, 225-227.

Nozdrina, L. (2009). Poetika grammaticheskih kategoriy [Poetics of grammatical categories]. Moscow, Russia: ZGB.

Pavlova, T. (2011). Lingvokul'turologicheskie harakteristiki kommunikativnogo prostranstva detskoj pojezii: Na materiale anglijskih $i$ russkih stihov dlja detej [Linguoculturological characteristics of communicative space in children's poetry: On the material of English and Russian poetry for children] (Unpublished candidate dissertation). Immanuel Kant Baltic Federal University, Kaliningrad, Russia.

Ritvo, H. (1985). Learning history for children in the eighteenth and nineteenth centuries. Children's Literature Journal, 13, 72-93. Retrieved from http:// muse.jhu.edu/journals/chl/summary/v013/13.ritvo. html

Samson, A. (2005). Dare sexual discourse in NIYI Osundare's poetry: A sociological reading. Nigeria: African Study Minographs Journal, 26(2), 89 -97.

Schellenberger, K. (1996). From mother goose to the modern world: Contextualizing the development of children's poetry (Unpublished Master's thesis). University of Waterloo, Waterloo, Canada.

Sloan, G. (2001). But is it poetry? Children's Literature in Education Journal, 32, 45-56.

Sokolova, O. (2013). Reklamnye, agitacionnye $i$ avangardnye pojeticheskie teksty, adresovannye detjam: Kommunikativno-pragmaticheskij aspect [Advertising, agitational and avant-garde poetical texts addressed at children: Communicativepragmatic aspect]. Moscow, Russia: Filologicheskie nauki. Retrieved from http://www.gramota.net/ materials/2/2013/5-1/45.html

Stepanova, I. (2003). Lingvomental'nye $i$ lingvokulturologicheskie haracteristiki tradicionnyh anglijskih detskih stihov [Linguomental and linguoculturological characteristics of traditional English children's poems] (Unpublished dissertation). Chelyabinsk State University, Chelyabinsk, Russia.

Thorne, J. P. (1969). Poetry, stylistics and imaginary grammars. Journal of Linguistics, 5, 147-150.

Tricker, T. (2001). The animal poetry of Ted Hughes (Unpublished doctoral dissertation). University of Aberdeen, Aberdeen, UK. 


\section{Appendix 1}

\begin{tabular}{|c|c|}
\hline Poems for children & Poems for adults \\
\hline 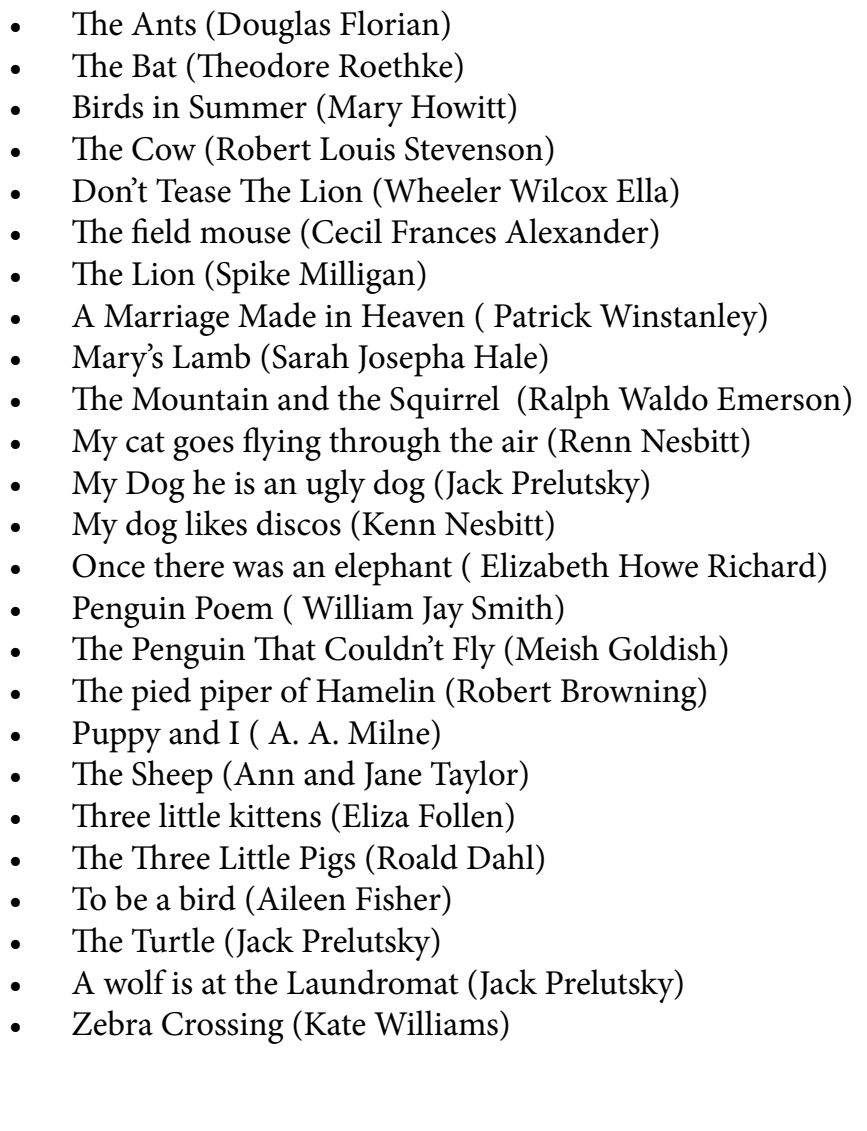 & $\begin{array}{ll}\text { - } & \text { Abandoned Dog (Robert William Service) } \\
\text { - } & \text { The Blind Men and the Elephant (John Godfrey } \\
\text { - } & \text { To a Butterfly (William Wordsworth) } \\
\text { - } & \text { The Cat And The Moon (William Butler Yeats) } \\
\text { - } & \text { Cuckoo (William Wordsworth) } \\
\text { - } & \text { The Darkling Thrush (Thomas Hardy) } \\
\text { - An elegy on the Death of a Mad Dog (Oliver } \\
\text { - } \quad \text { Toldsmith) } \\
\text { - To Flsh (Bishop Elizabeth) } \\
\text { - The Fly (William Blake) } \\
\text { - The Frog (Hilaire Belloc) } \\
\text { - The Hyaenas (Rudyard Kipling) } \\
\text { - Medusa (Louise Bogan) } \\
\text { - A Memorial to Boatswain (Lord Byron) } \\
\text { - A Minor Bird (Robert Frost) } \\
\text { - To a Mouse (Robert Burns) } \\
\text { - } \quad \text { On the Grasshopper and Cricket (John Keats) } \\
\text { - The Raven (Poe Edgar Allan) } \\
\text { - Shiv and the Grasshopper (Rudyard Kipling) } \\
\text { - To a Skylark (William Wordsworth) } \\
\text { - Snake (Denise Levertov) } \\
\text { - Snake (Padraic Colum) } \\
\text { - Sonnet to the Nightingale (John Milton) } \\
\text { - The Tiger (William Blake) } \\
\text { - A Wrens Nest (William Wordsworth) }\end{array}$ \\
\hline
\end{tabular}

